Бродецька Л.О.

\title{
Оптимізація лікування ретенованих зубів з нестачею місця в зубному ряду з урахуванням мультидисциплінарного підходу
}

Національний медичний університет імені О.О. Богомольця МОЗ України, м. Київ, Україна

klitinskaoksana@i.ua

\author{
Бродецкая Л.О. \\ Оптимизация лечения ретенированных зубов \\ с недостачей места в зубному ряду с учетом \\ мультидисциплинарного подхода \\ Национальний медицинский университет \\ имени А.А. Богомольца МЗ Украины, г. Киев, Украина
}

Brodetska L.O.

Optimization of treatment of retained teeth with lack of places in the dental taking into account the multidisciplinary approach

O. Bohomolets National Medical University of Ministry of Health of Ukraine, Kyiv, Ukraine
Стаття виконана в рамках наукової теми кафедри ортодонтії та пропедевтики ортопедичної стоматології стоматологічного факультету Національного медичного університету імені О.О. Богомольця «Мультидисциплінарний підхід до клініки, діагностики, лікування аномалій i деформацій окремих зубів, зубних рядів i прикусу» (№ державної реєстрації 0112U001417).

\section{Встуі}

Зуби, які через два роки після строку фізіологічного прорізування частково або повністю залишаються у кістковій тканині або під слизовою оболонкою в літературних джерелах називаються ретенованими $[1,5,6,14,16]$. За даними провідних вчених ретенція зубів фронтальної групи є найбільш поширеною патологією, викликає максимальну кількість скарг у пацієнтів не лише на естетичний дефект, а й на порушення функціонування зубо-щелепної системи в цілому $[4,13,14,20,21]$. Ретенція зубів $\epsilon$ однією 3 нагальних проблем сучасної ортодонтичної науки, що постійно ставить нові питання у підходах етіології, діагностики та вибору раціонального методу лікування $[3,4,8,9,17,18]$. Відомо ціла низка методів лікування ретенованих зубів, проте на сучасному етапі науково не обгрунтовано підхід до вибору методу лікування, не встановлені критерії вибору послідовності етапів та термінів проведення лікувальних заходів, відповідно ефективність результатів лікування носить імперативний характер та $є$ потреба у встановленні чіткого алгоритму здійснення діагностично-лікувальних заходів.

Мета - підвищення ефективності ортодонтичного лікування ретенованих зубів (РЗ) із нестачею місця в зубному ряду, шляхом мультидисциплінарного обгрунтування діагностично-лікувальних заходів на підставі вивчення молекулярних механізмів порушення кісткового ремоделювання процесів прорізування зубів та диференційованого застосування ортодонтичних зусиль залежно від виду прикусу.

\section{Матеріали та методи}

Для досягнення мети були відібрані 109 пацієнтів із ретенованими зубами, віком 9-35 років, які мали Р3 із нестачею місця в зубному ряду, з них 69 жіночої статі $(63,3 \%)$ та 40 чоловічої (36,7\%). Лікування проводилось у Стоматологічному медичному центрі Національного медичного університету імені О.О. Богомольця впродовж 2017-2019 років (директор: Копчак А.В.). Здійснювалася наукова співпраця 3 інститутом механіки імені С.П. Тимошенка НАН України (директор: Гузь О.М. академік НАН України), НДІ експериментальної та клінічної медицини НМУ імені О.О. Богомольця (директор: Натрус Л.В. - д.мед.н., професор).

Пацієнтам у змінному прикусі $(\mathrm{n}=62)$ проводилося клініко-рентгенологічне дослідження із визначенням просторового розташування Р3 та ортодонтичне лікування знімними апаратами із терапевтичним стоматологічним супроводом протягом лікування. Пацієнтам із постійним прикусом $\quad(\mathrm{n}=47)$ після клініко-рентгенологічного дослідження із визначенням анатомо-топографічного положення Р3 в кістці альвеолярного відростку проводилося ортодонтичне лікування із застосуванням брекет-системи і лікування терапевтом стоматологом.

Пацієнтам із Р3 та без них $(n=18)$ проведено оцінку стану цитокінової системи в кістковій тканині альвеолярного відростку [19].

Клінічні методи були застосовані для оцінки місцевого статусу та визначення стану тканин пародонту, твердих тканин зуба за показниками (індекс гігієни порожнини рота, проба Шиллера-Писарева, КПВ, КПВ+кп) $[1,6,14,20]$; рентгенологічні - для визначення рентгенологічних характеристик Р3 із використанням 
ортопантомограм та 3D KT [1,2,5,9]; статистичні - для встановлення об'єктивності отриманих результатів дослідження за допомогою комп'ютерних програм MS Exel та Origin [7,10].

\section{Результати дослідження та їх обговорення}

На основі проведених експериментальних, рентгенологічних та клінічних досліджень був розроблений діагностично-лікувальний комплекс заходів для пацієнтів із Р3 із нестачею місця в зубному ряду, залежно від періоду прикусу, що складався 3 наступних блоків: мотиваційного, діагностичного та лікувального.

Мотиваційний блок запропонованого діагностичнолікувального комплексу розроблений відповідно до вікової періодизації розвитку людини. Він є одним 3 базових та регуляційних компонентів в роботі ортодонта, який оптимізує лікувальний процес, налагоджує зв'язок «лікар-пацієнт-батьки», сприяє виконанню рекомендацій, формує та розвиває розуміння важливості ортодонтичного лікування.

Діагностичний блок передбачав стандартний набір обстежень для пацієнтів із Р3 не залежно від періоду прикусу. Ортодонт обов'язково включав оцінку ортодонтичного статусу, який передбачав визначення: виду прикусу; відсутність певного зуба в зубному ряду відповідно до строків прорізування на верхній та нижній щелепі; відсутність місця для нього в зубному ряду; на КТ визначав повну рентгенологічну характеристику Р3 в 3-ох площинах, стану його та поряд розташованих зубів, кісткової тканини, глибину залягання, зміщення відносно оклюзійної площини, дефіцит місця в зубному ряду; на ортопантомограмі: КТ топографію розміщення зуба, нахил поздовжньої осі Р3, рівень симетрії та відповідності розмірів бічних, передніх і фронтальних сегментів щелеп iз наявними Р3. На цьому етапі дослідження - хірург оцінює клінічний хірургічний статус 3 метою доступу до Р3; за даними КТ розраховує положення Р3 та підхід до нього (а саме, зміщення за сагітальною площиною вестибулярно або піднебінно-лінгвально поверхні, та за вертикаллю - відносно краю альвеолярного відростку), визначає спосіб доступу до кістки альвеолярного відростку та відкриття коронки Р3. Терапевт-стоматолог до початку ортодонтичного лікування визначає та оцінює клінічний терапевтичний статус, із врахуванням показників індексів: КПВ, КПВ+кп, РМА, проби Шиллера-Писарева, які характеризують стан гігієни порожнини рота, м'яких та твердих тканин зубів, для того, щоб протягом ортодонтичного лікування проводити санацію порожнини рота і лікування зубів. У випадках, коли Р3 залягає глибоко та має зміщення одночасно в трьох площинах, для вирішення питання можливості його переміщення проводиться прогностичний тест [12] щодо процесів резорбції та формування кісткової тканини за показниками маркерів апоптозу прокаспази та RANKIRANKL, OPGIRANKL.

Лікувальний блок передбачав ортодонтичні, хірургічні, терапевтичні заходи залежно від періоду прикусу. У ЗП на підготовчому етапі ортодонт створює місце для Р3 із вперше запропонованим [11] та застосуванням ортодонтичного гвинта із силою, що дорівнює 5,69 Н та апарату-прототипу. Терапевтстоматолог проводить лікувальні заходи для тканин пародонту, санує порожнину рота, здійснює контроль лікування за показаннями. Хірург стоматолог вибирає доступ до РЗ та відкриває вестибулярну поверхню коронки або іiі частини; ортодонт проводить фіксацію тягового анкеру з лігатурами.

Етап виведення Р3 передбачає використання власного знімного ортодонтичного апарату та апаратупрототипу із застосуванням визначених сил, необхідних для переміщення Р3 залежно від групової приналежності його, етапу переміщення (в кістці або екструзіi) із контролем ефективності лікування.

У постійному періоді прикусу на підготовчому етапі ортодонт із використанням ортодонтичної пружини створює місце для Р3; терапевт-стоматолог проводить лікування захворювань тканин пародонту із гігієнічними заходами; хірург-стоматолог визначає доступ до Р3 та відкриває вестибулярну поверхню коронки або ії частину; ортодонт фіксує тяговий анкер з лігатурою.

На етапі виведення Р3 в ПП використовують брекетсистему та здійснюють контроль ефективності лікування.

Результати хірургічної підготовки Р3 залежно від їх клініко-рентгенологічних характеристик. Дані рентгенологічних характеристик Р3 у ЗП щодо зміщення їх за трьома площинами виявили, що середні значення глибини залягання зубів залежно від їх групової приналежності становили: для різців - 6,66 1,61 ; ікла -

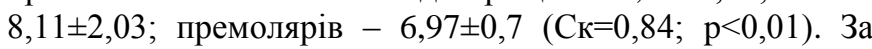
сагітальною площиною зміщення Р3 у вестибулярний бік превалювало у 3,5 разів над піднебінно-лінгвальним, при цьому ікла в 2 рази частіше займали вестибулярне положення. У $3 П 35$ Р3 мали кут нахилу до $10^{\circ}$ відносно оклюзійної площини, а 54 Р3 - більше $10^{\circ}$. Середній кут нахилу становив для перших премолярів $-17,6^{\circ} \pm 3,21$; різців $-14,1^{\circ} \pm 6,23$; ікла $-13,85^{\circ} \pm 8,09$. Середній дефіцит місця в зубному ряду в ЗП найбільший був для ікол $(5,67 \pm 1,7)$, а на другому місці - для других премолярів $(4,95 \pm 1,06)($ Ск $=0,73 ; \mathrm{p}<0,01)$.

Рентгенологічна характеристика Р3 в період постійного прикусу встановила середні значення глибини залягання зубів залежно від їх групової приналежності: для різців 7,42 \pm 1 , ікла $7,48 \pm 0,99$, премолярів $6,77 \pm 0,99$ $(\mathrm{C \kappa}=0,84 ; \mathrm{p}<0,01)$; дефіциту місця: для різців 4,22 $\pm 0,61$,

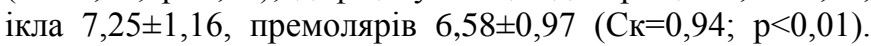
Кількість Р3 зміщених у вестибулярний та піднебінно/ лінгвальний бік достовірно не відрізнялися. У вестибулярний бік найчастіше зміщувалась фронтальна група зубів, а саме різці та ікла. У ПП Р3, які мали кут відхилення до $10^{\circ}$ та більше $10^{\circ}$ достовірно не відрізнялися за кількістю. Середні кути відхилення для різців становили $14,1^{\circ} \pm 6,23$; ікол - $15,0^{\circ} \pm 6,75$; премолярів $13,7^{\circ} \pm 3,1(\mathrm{C \kappa}=0,78 ; \mathrm{p}<0,01)$.

Усі пацієнти були розподілені на три групи залежно від методики формування доступу до РЗ. До складу першої групи увійшло 35 пацієнтів, яким доступ проводився 
відкритим хірургічним способом; другої - 53 пацієнта, яким доступ формувався за допомогою високоенергетичного лазерного випромінювання лазерною системою («FONA lazer» Німеччина); третьої 21 особа, яким втручання на слизово-окісній тканині проводилося за допомогою діатермокоагулятора (Svarog).

Хірургічний етап по вивільненню Р3 проводили у пацієнтів із ЗП та ПП. При проведені оперативного втручання враховували положення зуба (вестибулярне, піднебінне, лінгвальне), глибину залягання Р3, кут відхилення по відношенню до оклюзійної площини.

Хірургічний підготовчий етап передбачав: проведення провідникової анестезії, викроювання слизово-окісного клаптя; далі у разі вестибулярного або піднебінного положення при глибині залягання до 2 мм тонку кортикальну пластинку видаляли за рахунок елеватора або долота; при щільній кортикальній пластинці та глибині залягання більше 2 мм видалення кортикальної пластинки в зоні коронки Р3 проводили за допомогою бормашини та фрези Ліндемана; надалі ортодонт проводив фіксацію ортодонтичної кнопки або брекету для проведення виведення Р3; ушивання рани на всьому протязі, окрім місця виведення лігатури.

Хірургічний доступ на м'яких тканинах альвеолярного відростку (слизово-окісні) здійснювали трьома способами: із використанням скальпелю, лазеру, електрофульгуратору.

Аналіз вираженості больового синдрому та колатерального набряку у пацієнтів, яким було проведено хірургічне втручання для відкриття ретенованого зуба різним способами встановив достовірну різницю при використанні різних методів (табл. 1).

Таблиця 1. Динаміка больового синдрому та колатерального набряку тканин залежно від способу доступу до РЗ

\begin{tabular}{|c|c|c|c|c|c|c|c|}
\hline \multirow[t]{3}{*}{ Параметри } & \multirow{3}{*}{$\begin{array}{c}\text { Термін } \\
\text { спостереження } \\
\text { (доба) }\end{array}$} & \multicolumn{6}{|c|}{ Больовий синдром та колатеральний набряк } \\
\hline & & \multicolumn{2}{|c|}{ відсутні симптоми } & \multicolumn{2}{|c|}{ слабо виражені } & \multicolumn{2}{|c|}{ значно виражені } \\
\hline & & абс & $\%$ & абс & $\%$ & абс & $\%$ \\
\hline \multirow{3}{*}{ Перша (n=35) } & $3-я$ & - & - & 7 & 20,0 & 28 & 80,0 \\
\hline & $7-\mathrm{a}$ & 5 & 14,3 & 24 & 68,6 & 6 & 17,1 \\
\hline & $14-\mathrm{a}$ & 30 & 85,7 & 5 & 14,3 & - & - \\
\hline \multirow[t]{3}{*}{ Друга (n=53) } & $3-я$ & 14 & 26,24 & 33 & 62,3 & 6 & 11,3 \\
\hline & $7-\mathrm{a}$ & 38 & 71,7 & 15 & 28,3 & - & - \\
\hline & $14-a$ & 53 & 100 & - & - & - & - \\
\hline \multirow[t]{3}{*}{ Третя $(n=21)$} & $3-я$ & - & - & 3 & 14,3 & 18 & 85,7 \\
\hline & $7-a$ & 1 & 4,8 & 15 & 71,4 & 5 & 23,8 \\
\hline & $14-a$ & 12 & 57,1 & 9 & 42,9 & - & - \\
\hline \multirow[t]{3}{*}{ Разом $(\mathrm{n}=109)$} & $3-я$ & 14 & 12,84 & 43 & 39,4 & 52 & 47,7 \\
\hline & $7-a$ & 44 & 40,4 & 54 & 49,5 & 11 & 10,1 \\
\hline & $14-a$ & 95 & 87,2 & 14 & 12,8 & - & - \\
\hline \multicolumn{8}{|c|}{$\mathrm{p}<0,05$} \\
\hline
\end{tabular}

Відсутність больових відчуттів та колатерального набряку спостерігалося у пацієнтів другої групи, яким доступ формувався за допомогою високоенергетичного лазерного випромінювання на третю (вестубулярно, піднебінно) у 26,24\% (n=14), сьому у 71,7\% (n=38) та чотирнадцяту добу у $100,0 \%(\mathrm{n}=53)$ пацієнтів. Помірно вираженого больового синдрому та колатерального набряку не відмічалося взагалі впродовж всього терміну спостереження.

При використанні класичного хірургічного методу на третій день у 20,0\% (n=7) відмічався слабкий біль та набряк, а 80,0\% $(\mathrm{n}=28)$ сильні больові відчуття та набряк. На сьому добу превалював слабо виражений больовий синдром та колатеральний набряк у $68,6 \%(\mathrm{n}=24)$, помірно виражений у 17,1\% (n=6) та повна відсутність болю та набряку достовірно не відрізнялися між собою у 14,3\% $(\mathrm{n}=5)(\mathrm{p}>0,05)$. Через 14 діб після втручання превалювала відсутність болю та набряку у 85,7\% $(\mathrm{n}=30)$, та невелика кількість пацієнтів 14,3\% (n=5) відмічали слабо виражені больові відчуття та колатеральний набряк.
У пацієнтів третьої клінічної групи, яким формування доступу проводилось за допомогою діатермокоагулятора, через три доби превалювали помірні больові відчуття та колатеральний набряк $(85,7 \%$ 18 осіб); через сім діб - слабо виражений біль та набряк (71,4\% - 15 осіб), а через 14 діб недостовірна відмінність відсутності болю і набряку та слабких больових відчуттів і набряку $(57,1 \% ; 42,9 \% ; \mathrm{p}>0,05)$.

Результати вивчення вираженості больового синдрому при використанні різних способів вивільнення Р3 показали, що відсутність больового синдрому та колатерального набряку спостерігали на 3-тю добу в 2 групі (використання лазеру) - 26,24\% ( $n=14)$.

Результати ортодонтичного лікування P3 із нестачею місця в різні періоди прикусу. Для лікування за запропонованим комплексом були включені пацієнти 3 P3 фронтальної групи, оскільки при вивченні поширеності Р3 показало, що ретенція саме цих груп зубів була найчисленнішою. Зокрема, в змінному прикусі (ЗП) 
ретеновані ікла становили $51,7 \% \quad(42,7 \%$ на верхній щелепі), другі премоляри - у $18,0 \%$, ретеновані та латеральні різці - 15,7\% (12,3\% на верхній щелепі). В період змінного прикусу у 62 пацієнтів було виявлено всього 89 Р3, 3 яких до 1 групи $\left(13 \mathrm{a}_{1}, \mathrm{a}_{2}\right)$ увійшли 22 пацієнти, які мали 22 Р3 (31,42\%), а до 2 групи (23Па $1, \mathrm{a}_{2}$ та 23Пб $\left.{ }_{1}, \sigma_{2}\right)$ - 40 пацієнтів із 48 Р3 (68,56\%). 13Па $a_{1, a_{2}}$ група - 22 пацієнти, які мали 22 ретенованих фронтальних зубів та премолярів, розміщених у вертикальному положенні - 31,42\% ( $=22)$, розподілені на дві підгрупи залежно від глибини залягання РЗ: до 7 мм 13Па 1 - (10 зубів - 14,28\%) та більше 7 мм 13Па 2 (12 зубів - 17,14\%).

До 2 ЗП групи увійшли 40 пацієнтів 348 Р3 (68,56\%) фронтальної групи та премолярами, котрі зміщені у трьох площинах з розподілом відповідно до глибини залягання P3: 2а ЗП до 7 мм та 2б ЗП більше 7 мм (табл. 2).

Таблиця 2. Розподіл Р3 в період змінного прикусу (а - апарат власної конструкції; б - апарат прототип)

\begin{tabular}{|c|c|c|c|c|c|c|}
\hline Кількість зміщених площин & \multirow{2}{*}{\multicolumn{2}{|c|}{$\begin{array}{c}\text { Зміщені в одній площині } \\
1 \text { ЗПа } \mathrm{a}_{1} \text { (n=22; } 22 \text { Р3) }\end{array}$}} & \multicolumn{4}{|c|}{ Зміщені в 2-ох площинах 2 3П (n=40; 48 P3) } \\
\hline \multirow{2}{*}{ Клінічні групи } & & & \multicolumn{2}{|c|}{$23 \Pi a_{1, a_{2}}$} & \multicolumn{2}{|c|}{$23 \Pi \sigma_{1, \sigma_{2}}$} \\
\hline & абс. & $\%$ & абс. & $\%$ & абс. & $\%$ \\
\hline \multicolumn{7}{|l|}{ Глибина залягання } \\
\hline до 7 мм* & 10 & 14,28 & 10 & 14,28 & 10 & 14,28 \\
\hline більше 7 мм** & 12 & 17,14 & 14 & 20 & 14 & 20 \\
\hline Всього & 22 & 31,42 & 24 & 34,28 & 24 & 34,28 \\
\hline
\end{tabular}

Таблиця 3. Поетапне лікування Р3 у ЗП

\begin{tabular}{|c|c|c|}
\hline $\begin{array}{c}\text { Клінічні } \\
\text { групи }\end{array}$ & $\begin{array}{c}\text { Вид } \\
\text { ортодонтичного } \\
\text { лікування }\end{array}$ & Створення місця для Р3 \\
\hline $\begin{array}{l}13 \Pi a_{1}, a_{2} \\
(n=22) \\
22 \text { P3 }\end{array}$ & $\begin{array}{l}\text { Ортодонтичний } \\
\text { апарат власної } \\
\text { конструкції }\end{array}$ & $\begin{array}{l}\text { Створення на 50\% місця } \\
\text { в зубній дузі для Р3 } \\
\text { (гвинт силою 5,69 Н). } \\
\text { Одночасне виведення Р3 } \\
\text { із ортодонтичною силою } \\
\text { залежно від групової } \\
\text { приналежності зуба }\end{array}$ \\
\hline
\end{tabular}

\begin{tabular}{l|l|l|}
$\begin{array}{l}23 \mathrm{a}_{1, \mathrm{a}_{2}} \\
(\mathrm{n}=20)\end{array}$ & $\begin{array}{l}\text { Ортодонтичний } \\
\text { апарат власної } \\
\text { конструкції }\end{array}$ & $\begin{array}{l}\text { Створення на 50\% місця } \\
\text { в зубній дузі для Р3 } \\
\text { (гвинт силою 5,69 Н). } \\
\text { Одночасне виведення Р3 } \\
\text { iз ортодонтичню силою } \\
\text { залежно від групової } \\
\text { приналежності зуба }\end{array}$ \\
\hline $\begin{array}{l}\text { 23Пб }, \sigma_{2} \\
\text { (n=20) }\end{array}$ & Апарат прототип & $\begin{array}{l}\text { Після виведення Р3 - } \\
\text { створення місця } \\
\text { апаратом Шварца 3 } \\
\text { гвинтом }\end{array}$ \\
\hline
\end{tabular}

\section{Стимулю- вання P3}

Стимуляція за рахунок штучних ясен в області Р3

Стимуляція
за рахунок
штучних
ясен в
області Р3
Без
$\begin{aligned} & \text { стимулю- } \\ & \text { вання Р3 }\end{aligned}$

\section{Виведення P3} коронки P3

Коронки або іiі частини залежно від зміщення вестибулопіднебінно лінгвальне на етапі створення $50 \%$ місця для Р3

\section{Одразу у трьох} площинах 3 одночасним стимулюванням Заміна ортодонтичної тяги залежно від площі контакту Р3 з кісткою

\begin{tabular}{|c|c|}
\hline $\begin{array}{l}\text { Коронки або їі } \\
\text { частини залежно } \\
\text { від зміщення } \\
\text { вестибуло- } \\
\text { піднебінно- } \\
\text { лінгвальне на } \\
\text { етапі створення } \\
\text { 50\% місця для Р3 }\end{array}$ & $\begin{array}{l}\text { Одразу у трьох } \\
\text { площинах } 3 \\
\text { одночасним } \\
\text { стимулюванням } \\
\text { Заміна } \\
\text { ортодонтичної } \\
\text { тяги залежно від } \\
\text { площі контакту } \\
\text { Р3 з кісткою }\end{array}$ \\
\hline $\begin{array}{l}\text { Коронки або їі } \\
\text { частини залежно } \\
\text { від зміщення } \\
\text { вестибуло- } \\
\text { піднебінно- } \\
\text { лінгвальне на етапі } \\
\text { через місяць після } \\
\text { сдачі апарату }\end{array}$ & $\begin{array}{l}\text { Поетапно в } \\
\text { кожній площині } \\
\text { окремо }\end{array}$ \\
\hline
\end{tabular}

Поетапність лікування в $13 П\left(13 П a_{1}, 13 \mathrm{Ia}_{2}\right)$ та 23Па 1 , $\mathrm{a}_{2}$ проводилося за схемою.

При глибині залягання Р3 в альвеолярному паростку до 7 мм 20 Р3 (13Па 1 та 23Па 1$)(28,56 \%)$ та 26 Р3 3 глибиною залягання більше 7 мм (13Па 2 та 23Па 2$)$ лікування здійснювалося 3 використанням розробленого ортодонтичного апарату (патент України № 136794, 2019 р.) та обгрунтованого на основі механікоматематичного моделювання $з$ урахуванням вимог, щодо переміщення Р3.

Для пацієнтів цих груп застосовувався власний ортодонтичний апарат, в якому були враховані такі 
конструктивні елементи: V-подібний гвинт, за рахунок якого проводилося корпусне переміщення зубів для створення місця для Р3 силою 5,69 Н та активацією його кожні 5 днів; для переміщення Р3 застосовувалися еластична тяга в залежності від групової приналежності зуба (для різців та премолярів від 85 до 100 г (3,5 oz), для ікол - 130 г (4,5 oz)), які змінювалися кожні 3 години, а на кінцевому етапі екструзії Р3 вони підбираються відповідної сили, але меншого діаметру. Стимуляція прорізування Р3 проводилася одночасно із переміщенням Р3 за допомогою високо розміщених штучних ясен в області проекції Р3, 3 метою запуску процесів апоптозу в кістковій тканині. Фіксація тяг здійснювалася на плече з ланкою для спирання ïх та гачків в базисі апарату, які були розміщені із врахуванням переміщення Р3 в трьох площинах.

Для порівняння ефективності використання запропонованого ортодонтичного апарату лікування в групі
23Пб, б, здійснювали апаратом Бабаскіна (патент України № 7549, 2005 р.) 3 порівнянням термінів лікування. Попередньому такому ортодонтичному лікуванню здійснювалося хірургічне вивільнення коронки Р3.

Цей апарат мав відповідні конструктивні елементи: плече, що має ланку для спирання еластичної тяги, що змінювалася кожні 3 години, та підбиралися залежно від визначення необхідної сили для різців та премолярів від 85 до 100 г (3,5 oz), для ікол - 130 г (4,5 oz).

При використанні розробленого ортодонтичного апарату терміни переміщення Р3 достовірно скорочувалися у основних групах у порівнянні 3 термінами лікування у групі порівняння, в групі 13 Па $\mathrm{a}_{1} \mathrm{a}_{2}$ достовірність становила Ск=0,74; $<<0,05 ;$ в 23Па $\mathrm{a}_{1} \mathrm{a}_{2}$ Ск $=0,89 ; \quad \mathrm{p}<0,05 ; \quad$ в $23 П \sigma_{1}, \sigma_{2} \quad$ Ск $=0,84 ; \quad \mathrm{p}<0,05$. Що $€$ підтвердженням ефективності застосування запропонованого ортодонтичного апарату (табл. 4).

\section{Таблиця 4. Терміни переміщення Р3 в період змінного прикусу (міс.)}

\begin{tabular}{|c|c|c|c|}
\hline К-сть зміщених площин & в одній площині & \multicolumn{2}{|c|}{ в 2-ох площинах } \\
\hline Клінічні групи & \multirow{2}{*}{$13 \mathrm{a}_{1, \mathrm{a}_{2}}(\mathrm{n}=22 ; 22$ P3) } & \multicolumn{2}{|c|}{$23 \Pi(n=40 ; 48$ P3) } \\
\hline Глибина залягання & & $23 \Pi \mathbf{a}_{1}, \mathbf{a}_{2}$ & $23 \Pi \boldsymbol{\sigma}_{1, \mathbf{0}_{2}}$ \\
\hline до $7 \mathrm{Mм}$ & $3,12 \pm 0,01$ & $5,10 \pm 0,21$ & $8,75 \pm 2,21$ \\
\hline більше 7мм & $5,34 \pm 0,02$ & $7,31 \pm 0,21$ & $12,11 \pm 2,01$ \\
\hline Ск-кореляція & Ск $=0,74$ & Ск $=0,89$ & СК $=0,84$ \\
\hline p-достовірність & $\mathrm{p}<0,05$ & $\mathrm{p}<0,05$ & $\mathrm{p}<0,05$ \\
\hline
\end{tabular}

Аналізуючи отримані результати лікування Р3 апаратами різної конструкції слід зазначити наступні тенденції, що терміни виведення Р3 залежать, як від клініко-рентгенологічних його характеристик (глибини залягання, зміщення відносно 3-ох площин), етапності підготовчих хірургічних заходів, так i конструкції ортодонтичного апарату.

У разі зміщення Р3 за однією вертикальною площиною при ортодонтичному лікуванні із застосуванням запропонованого апарату вивести Р3 вдається в 1,7 разів швидше при глибині залягання до 7 мм $\left(13 П \mathrm{a}_{1}\right)$ ніж більше 7 мм $\left(13 \mathrm{I}_{2}\right)(\mathrm{C \kappa}=0,74 ; \mathrm{p}<0,05)$.

При порівнянні термінів лікування ретенованих зубів, у період змінного прикусу, які зміщені в трьох площинах спостерігалося достовірне скорочення термінів лікування при використанні авторського ортодонтичного апарату у порівнянні 3 ортодонтичним апараттом Бабаскіна, як при глибині залягання Р3 до 7 мм $(5,10 \pm 0,2$; $8,75 \pm 2,21 ; \mathrm{p}<0,05)$, так і при глибині залягання Р3 більше 7 мм $(7,31 \pm 0,21 ; 12,11 \pm 2,01 ; \mathrm{p}<0,05)$.

У групі 2 ЗП, де використовували запропонований та апарат - прототип для Р3 зміщених у декількох площинах, зберігаються ті ж самі тенденції, а саме :вивести Р3 при глибині залягання більше 7 мм довше в середньому в 1,35 рази $\left(\right.$ Ск $\left.=0,89, \mathrm{p}<0,05 ; \mathrm{C \kappa}^{2}=0,84, \mathrm{p}<0,05\right)$. Але порівнюючи ефективність застосування апарату в групі 2 ЗПа $1, \mathrm{a}_{2}(\mathrm{C \kappa}=0,89 ; \mathrm{p}<0,05)$ та 2 ЗПб,$_{2} \sigma_{2}(\mathrm{C \kappa}=0,84$; $\mathrm{p}<0,05)$, відмічається, що в 1,7 рази швидше досягається результат із використанням запропонованого апарату при різній глибині залягання.
Щодо залежності термінів лікування при зміщені Р3 в одній та трьох площинах, то вони відрізняються в декілька разів, як між собою, так і при застосуванні апаратів різної ортодонтичної конструкції.

Ефективніть лікування Р3 зміщених в одній площині при глибині залягання до 7 мм у разі застосування апарату власної конструкції в середньому в 1,6 разів досягалося швидше, ніж при зміщені Р3 в 3-ох площинах. А при використанні апарату - прототипу ці терміни збільшувалися в 2,8 разів. Та ж тенденція термінів лікування зберігалася і при глибокому заляганні Р3 відповідно 1,4 та 2,3 рази. Достовірне скорочення термінів лікування свідчить про ефективність застосування авторського ортодонтичного апарату при лікуванні ретенованих зубів в період змінного прикусу та рекомендовано до застосування його в практичній стоматології.

Отримані дані підтвердили високу ефективність застосування розробленого комплексу хірургічноортодонтично-терапевтичних заходів лікування Р3 в період змінного прикусу, який включає ретельну діагностику з визначенням розміщення ретенованого зуба в щелепі (глибина залягання, кут нахилу та наявність місця 3 зубному ряду) та вибору етапності лікування 3 урахуванням міждисциплінарного підходу, застосування запропонованого ортодонтичного апарату, із одночасним переміщенням Р3 в трьох площинах та стимуляцією зони P3, та поєднання 3 хірургічним методом та постійним терапевтичним супроводом. Запропонований 
діагностично-лікувальний комплекс може бути вибором для лікування РЗ в період змінного прикусу.

Нормалізація показників індексу РМА та проби Шилера-Писарева після лікування терапевтомстоматологом доводить ефективність запропонованого мультидисциплінарного підходу до лікування Р3 в період змінного прикусу. Результати індексу РМА після лікування показали переважання легкого ступеню 83,33\% та $85 \%(\mathrm{C \kappa}=0,82, \mathrm{p}=0,05)$. Важкого ступеня виявлено не було, тоді як до лікування він спостерігався у $11,9 \%$ дівчат та у 10\% хлопців, а показники легкого та середнього ступеня були нижчими (табл. 5).

Результатом ефективності мультидисциплінарного підходу до лікування Р3 було достовірне покращення показників проби Шиллера-Писарєва у пацієнтів зі ЗП (табл. 6)
Дані свідчать про превалювання негативної та слабо-позитивної проби (80,6\% та $70 \%$; Ск $=0,81 ; \mathrm{p}<0,05$ та 21,0\%; Ск=0,74; p=0,10), що достовірно відрізняється від показників при первинному огляді відповідно: (37,1\%; $19,4 \% ;$ Ск=0,74; p=0,10). Позитивна проба після лікування не діагностувалася в жодному випадку.

У ЗП відмічалося після лікування зниження поширеності карієсу у хлопців з $69,5 \pm 2,1$ до $62,3 \pm 1,7$, а у дівчат з $66,2 \pm 2,3$ до $56,2 \pm 1,3$, та достовірне зниження інтенсивності карієсу у хлопців $310,1 \pm 1,1$ до $5,1 \pm 0,9$

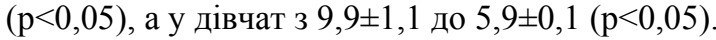

Динаміка показників стану гігієни порожнини рота також підтвердила ефективність проведення терапевтичних заходів та створення оптимальних умов для проведення ортодонтичного лікування (табл. 7).

\section{Таблиця 5. Результати індексу РМА в ЗП після лікування}

\begin{tabular}{|c|c|c|c|c|c|}
\hline \multirow{2}{*}{$\begin{array}{l}\text { Ступінь } \\
\text { Групи }\end{array}$} & \multirow{2}{*}{ Ск кореляція } & \multicolumn{2}{|c|}{ Дівчата $(n=42)$} & \multicolumn{2}{|c|}{ Хлопці (n = 20) } \\
\hline & & абс. & $\%$ & абс. & $\%$ \\
\hline Легкий & Ск $=0,82, p=0,05$ & 35 & 83,33 & 17 & 85 \\
\hline Середній & Ск $=0,78, p=0,05$ & 7 & 16,66 & 3 & 15 \\
\hline Важкий & Ск $=0,80, p=0,05$ & 0 & 0 & 0 & 0 \\
\hline
\end{tabular}

Таблиця 6. Результати проби Шиллера-Писарева у пацієнтів з Р3 у ЗП в динаміці

\begin{tabular}{|c|c|c|c|c|c|c|c|}
\hline \multirow{2}{*}{$\begin{array}{l}\text { Групи } \\
\text { Інтерпретація }\end{array}$} & \multirow{2}{*}{$\begin{array}{c}\text { Ск-кореляція } \\
\text { р-достовірність }\end{array}$} & \multicolumn{2}{|c|}{ Хлопці (n = 20) } & \multicolumn{2}{|c|}{ Дівчата $(n=42)$} & \multicolumn{2}{|c|}{ Всього $(\mathrm{n}=62)$} \\
\hline & & абс. & $\%$ & абс. & $\%$ & абс. & $\%$ \\
\hline \multicolumn{8}{|c|}{ До лікування } \\
\hline Негативна & Ск $=0,74 ; p=0,10$ & 5 & 25,0 & 8 & 19,0 & 13 & 21,0 \\
\hline Слабо-позитивна & - & 7 & 35,0 & 16 & 38,1 & 23 & 37,1 \\
\hline Позитивна & - & 8 & 40,0 & 18 & 42,9 & 26 & 41,9 \\
\hline \multicolumn{8}{|c|}{ Після лікування } \\
\hline Негативна & Ск $=0,81 ; \mathrm{p}<0,05$ & 14 & $70,0^{*}$ & 36 & $85,7 *$ & 50 & $80,6^{*}$ \\
\hline Слабо-позитивна & & 6 & 30,0 & 6 & $14,2 *$ & 12 & $19,4 *$ \\
\hline
\end{tabular}

Позитивна

* - достовірність 3 показниками до лікування $\mathrm{p}<0,05$.

Таблиця 7. Стан гігієни порожнини рота у пацієнтів з РЗ у ЗП в динаміці

\begin{tabular}{|c|c|c|c|c|c|c|c|}
\hline \multirow{2}{*}{ Стан гігісни Групи } & \multirow{2}{*}{$\begin{array}{c}\text { Ск-кореляція } \\
\text { р-достовірність }\end{array}$} & \multicolumn{2}{|c|}{ Хлопці (n = 20) } & \multicolumn{2}{|c|}{ Дівчата (n = 42) } & \multicolumn{2}{|c|}{ Всього $(n=62)$} \\
\hline & & абс. & $\%$ & абс. & $\%$ & абс. & $\%$ \\
\hline \multicolumn{8}{|c|}{ До лікування } \\
\hline Добрий & Ск $=0,85 ; p<0,05$ & 2 & 10,0 & 5 & 11,9 & 7 & 11,3 \\
\hline Задовільний & & 4 & 20,0 & 12 & 28,6 & 16 & 25,8 \\
\hline Незадовільний & Ск $=0,79 ; p<0,05$ & 8 & 40,0 & 18 & 42,9 & 26 & 41,9 \\
\hline Поганий & & 6 & 30,0 & 7 & 16,6 & 13 & 21,0 \\
\hline \multicolumn{8}{|c|}{ Після лікування } \\
\hline Добрий & Ск $=0,81 ; p<0,001$ & 14 & $70,0^{*}$ & 36 & $85,7 *$ & 50 & $80,6^{*}$ \\
\hline Задовільний & & 4 & 20,0 & 3 & $7,1^{*}$ & 7 & $11,3^{*}$ \\
\hline Незадовільний & Ск $=0,83 ; p<0,05$ & 2 & $10,0^{*}$ & 3 & $7,1^{*}$ & 5 & $8,0^{*}$ \\
\hline
\end{tabular}

Поганий

*-достовірність 3 показниками до лікування $\mathrm{p}<0,05$. 
Після закінчення лікування у пацієнтів зі змінним прикусом діагностовано достовірне збільшення доброго стану гігієни (від 11,0\% до 80,0\%; Ск $=0,81 ; \mathrm{p}<0,001$ ); достовірне зниження задовільного (від 25,8\% до $11,3 \%$; Ск $=0,83 ; \mathrm{p}<0,05)$ та незадовільного стану гігієни (від $41,9 \%$ до $8,0 \% ; \quad$ Ск $=0,83 ; \quad \mathrm{p}<0,05)$. Після лікування відмічена повна відсутність показників на рівні поганої гігієни порівняно 3 показниками до лікування від $21 \%$.
Результати лікування Р3 із нестачею місця у постійному прикусі. В постійному прикусі нами було прийнято на лікування 40 пацієнтів від 12 до 35 років 355 Р3 (34 на верхній щелепі та 21 на нижній щелепі) iз нестачею місця. Всі вони були розподілені на дві клінічні групи з урахуванням клініко-рентгенологічних характеристик Р3 (глибини залягання та зміщення відносно площин) (табл. 8).

\section{Таблиця 8. Розподіл Р3 із нестачею місця в період постійного прикусу}

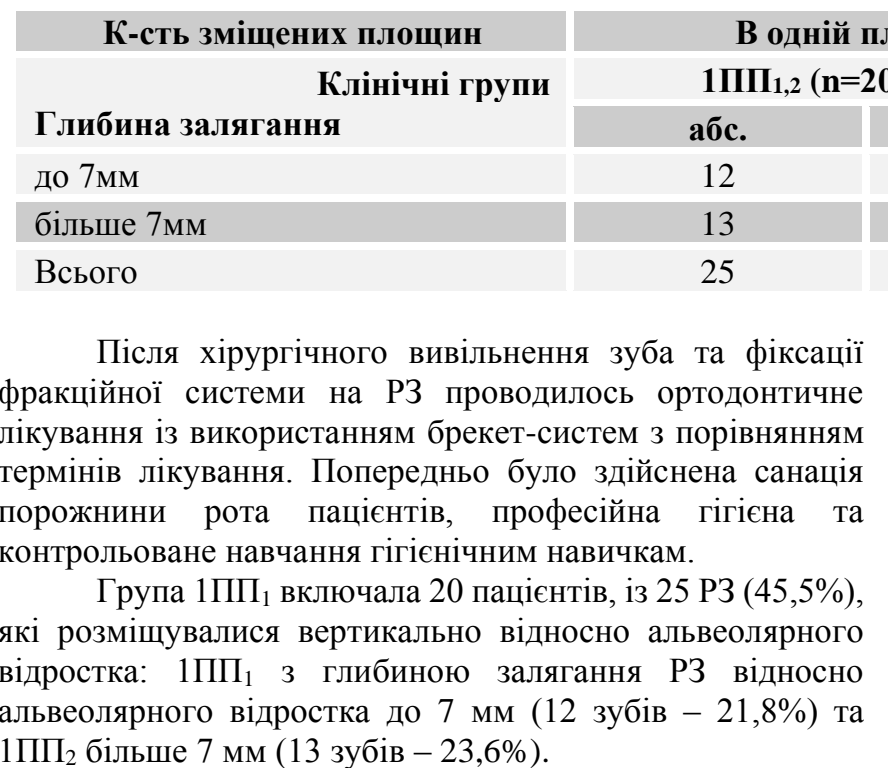

Таблиця 9. Поетапне лікування Р3 у ПП

\begin{tabular}{|c|c|c|c|c|c|}
\hline $\begin{array}{l}\text { Клінічні } \\
\text { групи }\end{array}$ & $\begin{array}{c}\text { Вид } \\
\text { ортодонтичного } \\
\text { лікування }\end{array}$ & $\begin{array}{c}\text { Створення } \\
\text { місця Для Р3 }\end{array}$ & $\begin{array}{c}\text { Стимулювання } \\
\text { P3 }\end{array}$ & $\begin{array}{c}\text { Хірургічне } \\
\text { відкриття } \\
\text { коронки Р3 }\end{array}$ & Виведення Р3 \\
\hline $\begin{array}{l}1 \Pi_{1,2}(n=20) \\
25 \text { P3 }\end{array}$ & Брекет-система & $\begin{array}{l}\text { Ортодонтична } \\
\text { розкриваюча } \\
\text { пружина }\end{array}$ & Відсутня & $\begin{array}{l}\text { Коронки або їі } \\
\text { частини } \\
\text { залежно від } \\
\text { зміщення } \\
\text { вестибуло- } \\
\text { піднебінно- } \\
\text { лінгвальне } \\
\text { після } \\
\text { створення 50\% } \\
\text { місця для Р3 }\end{array}$ & $\begin{array}{l}\text { Одночасно із } \\
\text { створенням місця } \\
\text { для Р3 змінюючи } \\
\text { силу тяги залежно } \\
\text { від групової } \\
\text { приналежності зуба }\end{array}$ \\
\hline $\begin{array}{l}2 \Pi_{1,2}(n=20) \\
30 \text { P3 }\end{array}$ & Брекет-система & $\begin{array}{l}\text { Ортодонтична } \\
\text { розкриваюча } \\
\text { пружина }\end{array}$ & Відсутня & $\begin{array}{l}\text { Коронки або її } \\
\text { частини } \\
\text { залежно від } \\
\text { зміщення } \\
\text { вестибуло- } \\
\text { піднебінно- } \\
\text { лінгвальне } \\
\text { після } \\
\text { створення 50\% } \\
\text { місця для Р3 }\end{array}$ & $\begin{array}{l}\text { Одночасне створення } \\
\text { місця для Р3 та } \\
\text { замінюючи силу } \\
\text { та напрям } \\
\text { ортодонтичної тяги } \\
\text { залежно від площі } \\
\text { контакту Р3 із } \\
\text { кісткою та його } \\
\text { групової } \\
\text { приналежності }\end{array}$ \\
\hline
\end{tabular}


Таблиця 10. Терміни лікування пацієнтів в період постійного прикусу в клінічних групах (міс.)

\begin{tabular}{|l|c|c|}
\hline \multicolumn{1}{|c|}{ Клінічні групи } & Зміщені в одній площині кут нахилу & Зміщені в 3-ох площинах кут нахилу \\
\hline Глибина залягання Р3 & $1 \Pi_{1,2}(\mathrm{n}=20$ iз $25 \mathrm{P} 3)$ & $2 \Pi_{1,2}(\mathrm{n}=20$ iз $30 \mathrm{P} 3)$ \\
\hline до 7мм & $5,05 \pm 0,42$ & $8,61 \pm 0,43^{*}$ \\
\hline більше 7мм & $7,12 \pm 1,52^{\circ}$ & $13,8 \pm 0,43 * \circ$ \\
\hline Ск-кореляція & $\mathrm{C \kappa}=0,64$ & $\mathrm{C \kappa}=0,56$ \\
\hline р-достовірність & $\mathrm{p}<0,05$ & $\mathrm{p}<0,05$ \\
\hline
\end{tabular}

* - достовірність показників між першою та другою групами $\mathrm{p}<0,05$;

○ - достовірність показників з різною глибиною залягання Р3 p<0,05.

У клінічних групах $2 \Pi_{1}$ та $2 \Pi_{2}$ відмічена та ж достовірна залежність, а саме збільшення строків виведення на 5,19 місяців при глибині залягання більше

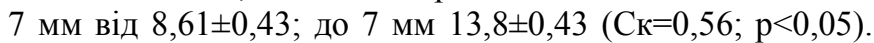
Порівнюючи терміни лікування Р3 із різною кількістю зміщення за площинами, і глибиною залягання до 7 мм $\left(1 \Pi_{1}\right.$ та $\left.2 \Pi_{1}\right)$ було встановлено їх подовження на 3,56 місяця (при розташуванні Р3 в сагітальній площині вестибулярно або піднебінно та 3 кутом нахилу $>10^{\circ}$ ) від $5,05 \pm 0,42$ до $8,61 \pm 0,43($ Ск $=0,56 ; \mathrm{p}<0,05)$.

Та ж закономірність була визначена і в групах $1 \Pi_{2}$ та $2 \Pi_{2} 3$ глибиною залягання $>7$ мм, а саме строки лікування збільшувалися майже на 7 місяців від 7,12 1 1,52 до $13,8 \pm 0,43$ (СК=0,56; $\mathrm{p}=0,05)$. У разі зміщення Р3 у трьох площинах $з$ глибиною залягання до 7 мм $2 \Pi_{1}-8,61 \pm 0,43$ та в одній площині більше 7 мм $1 \Pi_{2}-7,12 \pm 1,52$ строки лікування достовірно не відрізнялися. За умови зміщення Р3 в одній площині з глибиною залягання до 7 мм 1ПП $5,05 \pm 0,42$ строки лікування відрізнялися на 8,75 місяців порівняно з групою $2 \Pi_{2}-13,8 \pm 0,43$.

Проведене комплексне лікування Р3 в ПП показало також залежність строків лікування від клінікорентгенологічних характеристик Р3. При порівнянні впливу параметру глибини залягання Р3 в кожній групі $1 \Pi_{1,2}$ та $2 \Pi_{1,2}$ було встановлено, що в середньому строки лікування змінюються в 1,5 рази, а між собою в 1,8 рази $($ Ск=0,56; $\mathrm{p}<0,05)$. Зміни термінів лікування відбувалися найбільшими при різній глибині залягання Р3 та зміщення в різних площинах, а саме при одновекторному зміщенні та глибині залягання до 7 мм строки лікування зменшувались в 2,7 разів порівняно із Р3 із глибиною залягання більше 7 мм та зміщеного в 3-ох площинах. Встановлено, що строки лікування зубів, які були зміщені в 3-ох площинах із глибиною залягання до 7 мм в порівнянні із Р3, які були зміщенні в одній площині, але залягали глибше ніж 7 мм, майже не відрізнялися. Найбільш обтяженим фактором ризику є зміщення Р3 в трьох площинах, а на другому місці - глибина залягання, які суттєво впливають на строки лікування. Це $є$ свідченням про взаємообтяжуючий ефект зміщення Р3 за трьома площинами та глибиною залягання.

Результати міждисциплінарного підходу до лікування підтверджуються отриманими результатами лікування терапевта-стоматолога, а саме: проби ШиллераПисарева та РМА в процесі ортодонтичного лікування показали позитивну динаміку, що вказує на необхідність терапевтичного супроводу пацієнтів із Р3 (табл. 11).

Результати індексу РМА після лікування покращилися в 2 рази із превалюванням легкого ступеня $(\mathrm{C \kappa}=0,82, \mathrm{p}=0,05)$.

Проба Шиллера-Писарева виявилася негативною у $76,6 \%$ ( $<0,05)$ (табл. 12).

Після закінченні лікування у пацієнтів 3 постійним прикусом відмічається достовірне покращення показників гігієни порожнини рота. $70,0 \%$ осіб після лікування терапевтом мали добру гігієну порожнини рота $(\mathrm{C \kappa}=0,83 ; \mathrm{p}<0,05)$, повна відсутність показників на рівні поганої гігієни.

\section{Таблиця 11. Результати проби Шиллера-Писарева у паціснтів з РЗ у ПП в динаміці лікування}

\begin{tabular}{|c|c|c|c|c|c|c|c|}
\hline \multirow{2}{*}{ Інтерпретація } & \multirow{2}{*}{$\begin{array}{c}\text { Ск-кореляція } \\
\text { р-достовірність }\end{array}$} & \multicolumn{2}{|c|}{ Чоловіки $(\mathrm{n}=20)$} & \multicolumn{2}{|c|}{ Жінки (n = 27) } & \multicolumn{2}{|c|}{ Всього $(n=47)$} \\
\hline & & абс. & $\%$ & абс. & $\%$ & абс. & $\%$ \\
\hline \multicolumn{8}{|c|}{ До лікування } \\
\hline Негативна & - & 3 & 15,0 & 3 & 11,1 & 6 & 12,7 \\
\hline Слабо-позитивна & Ск $=0,79 ; p=0,10$ & 9 & 45,0 & 15 & 55,6 & 24 & 51,1 \\
\hline Позитивна & - & 8 & 40,0 & 9 & 33,3 & 17 & 36,2 \\
\hline \multicolumn{8}{|c|}{ Після лікування } \\
\hline Негативна & - & 15 & $75,0^{*}$ & 21 & $77,8^{*}$ & 36 & $76,6^{*}$ \\
\hline Слабо-позитивна & Ск $=0,64 ; p<0,05$ & 5 & $25,0^{*}$ & 6 & $32,2 *$ & 11 & $23,4^{*}$ \\
\hline Позитивна & - & - & - & - & - & - & - \\
\hline
\end{tabular}


Таблиця 12. Стан гігісни порожнини рота у паціснтів з Р3 у ПП в динаміці

\begin{tabular}{|c|c|c|c|c|c|c|c|}
\hline \multirow{2}{*}{ Стан гігісни Групи } & \multirow{2}{*}{$\begin{array}{c}\text { Ск-кореляція } \\
\text { р-достовірність }\end{array}$} & \multicolumn{2}{|c|}{ Чоловіки $(\mathrm{n}=20)$} & \multicolumn{2}{|c|}{ Жінки (n = 27) } & \multicolumn{2}{|c|}{ Всього $(n=47)$} \\
\hline & & абс. & $\%$ & абс. & $\%$ & абс. & $\%$ \\
\hline \multicolumn{8}{|c|}{ До лікування } \\
\hline Добрий & Ск $=0,75 ; p<0,05$ & 2 & 10,0 & 5 & 18,5 & 7 & 14,9 \\
\hline Задовільний & & 8 & 40,0 & 12 & 44,4 & 20 & 42,6 \\
\hline Незадовільний & Ск $=0,72 ; p<0,05$ & 6 & 30,0 & 6 & 22,2 & 12 & 25,5 \\
\hline Поганий & & 4 & 20,0 & 4 & 14,9 & 8 & 17,0 \\
\hline \multicolumn{8}{|c|}{ Після лікування } \\
\hline Добрий & Ск $=0,83 ; p<0,05$ & 16 & $80,0^{*}$ & 17 & $62,9^{*}$ & 33 & $70,2^{*}$ \\
\hline Задовільний & Ск $=0,85 ; \mathrm{p}<0,05$ & 2 & $10,0^{*}$ & 8 & $29,6^{*}$ & 10 & $21,3^{*}$ \\
\hline Незадовільний & & 2 & $10,0^{*}$ & 2 & $7,4^{*}$ & 4 & $8,5^{*}$ \\
\hline
\end{tabular}

* - достовірність 3 показниками до лікування $\mathrm{p}<0,05$.

Результати індексу РМА після лікування становили: у жінок: легкий - 77,8\%, середній $-22,2 \%$; у чоловіків: легкий ступінь $-65 \%$ і середній $-35 \%$. Важкого ступеня виявлено не було. Тоді як до лікування важкий ступінь РМА відмічали у всіх пацієнтів у наступних значеннях: у жінок - майже $15 \%$ і у чоловіків - $25 \%$. Показники легкого і середнього ступеня були нижчими.

Отже у результаті проведеного лікування всіх пацієнтів відповідно до індексу РМА, із важкого ступеня було переведено у середній та легкий, відповідно до чого показники останніх у відсотковому співвідношенні збільшилися, а рівень важкого ступеня знизився до позначки 0.

Результати міждисциплінарного підходу до лікування підтверджуються отриманими результатами лікування терапевта-стоматолога, а саме: проби Шиллера-
Писарева та РМА в процесі ортодонтичного лікування показали позитивну динаміку, що вказує на необхідність терапевтичного супроводу пацієнтів із Р3: індекс РМА покращився в 2 рази із превалюванням легкого ступеня $(\mathrm{C \kappa}=0,82, \mathrm{p}=0,05)$; проба Шиллера-Писарева виявилася негативною у 76,6\% (p<0,05) (табл. 13).

Отримані результати змін поширеності та інтенсивності карієсу у пацієнтів 3 Р3 в динаміці ортодонтичного лікування підтверджує необхідність проведення лікування твердих тканин зуба, що є запорукою ефективності ортодонтичного лікування (табл. 14).

У ПП відмічалося після лікування зниження поширеності карієсу у чоловіків $357,5 \pm 2,2$ до $37,5 \pm 1,2$, а у жінок $з 49,5 \pm 1,3$ до $34,2 \pm 0,9$, та достовірне зниження інтенсивності карієсу у чоловіків $39,0 \pm 1,1$ до $6,0 \pm 1,1$ $(\mathrm{p}<0,05)$, а у жінок $з 9,4 \pm 2,1$ до $3,4 \pm 0,1(\mathrm{p}<0,05)$.

Таблиця 13. Результати індексу РМА в ПП після лікування

\begin{tabular}{|l|c|c|c|c|c|}
\hline & Групи & Ск-кореляція & \multicolumn{2}{|c|}{ Жінки $(\mathbf{n = 2 7})$} & \multicolumn{2}{|c|}{ Чоловіки (n= 20) } \\
\hline Ступінь & p-достовірність & абс. & \% & абс. & \% \\
\hline Легкий & Ск $=0,82, \mathrm{p}=0,05$ & 21 & 77,77 & 13 & 35 \\
\hline Середній & $\mathrm{C \kappa}=0,83, \mathrm{p}=0,05$ & 6 & 22,22 & 7 & 0 \\
\hline Важкий & $\mathrm{C \kappa}=0,80, \mathrm{p}=0,05$ & 0 & 0 & 0 & 0 \\
\hline
\end{tabular}

Таблиця 14. Поширеність та інтенсивність каріссу серед паціснтів 3 Р3 залежно від періоду прикусу в динаміці ортодонтичного лікування, ум. од.

\begin{tabular}{|c|c|c|c|c|c|c|c|}
\hline \multicolumn{4}{|c|}{$3 \Pi(n=62)$} & \multicolumn{4}{|c|}{ ПП (n = 47) } \\
\hline \multicolumn{2}{|c|}{ Хлопці } & \multicolumn{2}{|c|}{ Дівчата } & \multicolumn{2}{|c|}{ Жінки } & \multicolumn{2}{|c|}{ Чоловіки } \\
\hline $\begin{array}{c}\text { Поширеність } \\
\text { карієсу }\end{array}$ & КПВ+кп & $\begin{array}{c}\text { Поширеність } \\
\text { карієсу }\end{array}$ & КПВ+кп & $\begin{array}{c}\text { Поширеність } \\
\text { карієсу }\end{array}$ & КПВ & $\begin{array}{c}\text { Поширеність } \\
\text { карієсу }\end{array}$ & КПВ \\
\hline \multicolumn{8}{|c|}{ До лікування } \\
\hline $69,5 \pm 2,1$ & $10,1 \pm 1,1$ & $66,2 \pm 2,3$ & $9,9 \pm 1,1$ & $57,5 \pm 2,2$ & $9,0 \pm 1,1$ & $49,5 \pm 1,3$ & $9,4 \pm 2,1$ \\
\hline \multicolumn{8}{|c|}{ Після лікування } \\
\hline $62,3 \pm 1,7$ & $5,1 \pm 0,9 *$ & $56,2 \pm 1,3$ & $5,9 \pm 0,1 *$ & $37,5 \pm 1,2$ & $6,0 \pm 1,1 *$ & $34,2 \pm 0,9$ & $3,4 \pm 0,1 *$ \\
\hline
\end{tabular}

* - достовірність 3 показниками до лікування $\mathrm{p}<0,05$. 
Перевагою запропонованої методики ортодонтичного лікування Р3 в ЗП, обтяжених нестачею місця в зубному ряду є можливість одночасного створення місця для Р3, виведення його в зубний ряд із застосуванням диференційованої ортодонтичної тяги залежно від стану переміщення та активації процесів кровообігу в області Р3 завдяки наявності високо розташованих штучних ясен в проекції Р3.

\section{Перспективи подальших досліджень}

Застосування мультидисциплінарного підходу до діагностично-лікувальних заходів лікування ретенованих зубів із нестачею місця в зубному ряду, із урахуванням молекулярних механізмів порушення кісткового ремоделювання процесів прорізування зубів та диференційованого застосування ортодонтичних зусиль залежно від виду прикусу дозволить підвищети ефективність лікування даної патології.

\section{Висновки}

Вивчення клініко-рентгенологічних характеристик Р3 з нестачею місця в зубній дузі дозволило виділити їх провідні критерії оцінки та встановити кореляційні зв'язки між кутом нахилу, глибиною залягання та зміщенням за трансверзальною і сагітальною площиною в змінному та постійному прикусах. Визначено, що зміщення Р3 в трьох площинах $\epsilon$ найбільш обтяжуючим фактором, який впливає на терміни лікування.

Вивчення протеїнів в каскаду апоптозу кісткових клітин встановило в зоні РЗ у порівнянні із зоною здорових зубів підвищення вмісту прокаспази-3 в 1,32 рази ( $<00,05)$ та накопичення неактивної форми каспази -3 в 1,78 рази $(\mathrm{p}<0,05)$. У зоні Р3 виявлено заблокований процес остеокластогенезу за рахунок не змінених показників медіатору NF-кB та NFATc1, що є свідченням дисбалансу у функціонуванні локальних цитокінових шляхів, відповідальних за остеорегуляцію у пацієнтів з Р3 і вказує на користь застосування методів механічного впливу для місцевої терапії.

Розроблений та впроваджений мультидисциплінарний діагностично-лікувальний, комплекс корекції Р3 з нестачею місця в зубному ряду на основі визначених клініко-рентгенологічних характеристик, молекулярних механізмів порушення кісткового ремоделювання, величини та способу застосування ортодонтичних зусиль, достовірно скорочує та підвищує ефективність ортодонтичного лікування пацієнтів з Р3, що підтверджують строки виведення РЗ у змінному прикусі в 1,7 разів швидше, ніж в постійному залежно від глибини залягання та зміщення за площинами.

\section{Література}

2. Айвазян АА, Недбай ВА, Кукушкин ВА. Диагностика и лечение ретенции резцов. Ортодент-инфо. $2001 ;(2): 35-37$

3. Головко НВ, Головко СВ, Король ДМ, та ін. Алгоритм розшифрування ортопантомограм. Український стоматологічний альманах. 2006;2(1): 9-11.

4. Дмитренко МІ. Застосування алгоритму лікування зубо-щелепних аномалій, ускладнених скученістю зубів. Лікарська справа. 2014;(1)2:72-77.

5. Добрий-вечір ТВ. Особливості хірургічного лікування хворих з утрудненим прорізуванням нижніх третіх молярів. [автореферат] Київ: Нац. мед. ун-т ім. О. О. Богомольця; 2011. 21с.

6. Клітинська ОВ. Епідеміологічний аналіз особливостей будови та функціонування щелепно-лицевого апарату у дітей Закарпаття, які постійно мешкають в умовах мікроелементозів. Молодий вчений. 2014; 8(11):112-114.

7. Кононенко ЮГ, Рожко ММ, Кіндрат ГВ, та ін. Довідник стоматолога. Методи обстеження, діагностика, клініка, лікування. Івано- Франківськ: НАІР; 2013. 384 с.

8. Мінцер ОП, Вороненко ЮВ, Власов ВВ. Оброблення клінічних і експериментальних даних у медицині: навч. посіб. Київ: Вища школа; 2003. 350с.

9. Оснач РГ, Тормахов НН, Беда АВ. Математическое обоснование применения ортодонтического метода замещения дефекта зубного ряда. Современная ортодонтия. 2014;(2):36-38.

10. Пилипів НВ. Особливості топічного розташування ретенованих зубів і їх систематизація. Український стоматологічний альманах. 2013;(4):64 - 68.

11. Реброва ОЮ. Статистический анализ медицинских данных. Применение пакета прикладных программ STATISTIKA. Москва:Медиа Сфера; 2002. 312 с.

12. Фліс ПС, Бродецька ЛО, винахідники; Національний медичний університет імені О.О. Богомольця, патентовласник. Ортодонтичний апарат для лікування ретенованого зуба з дефіцитом місця в зубному ряду. Патент України № 136794. 2019 Серпня 27.

13. Фліс ПС, Бродецька ЛО, Натрус ЛВ, Лісаковська ОО, винахідники; Національний медичний університет імені О.О. Богомольця, патентовласник. Спосіб оцінки ремоделювання кісткової тканини зубів. Патент України №136945. 2019 Вересень 10.

14. Фліс ПС, Бродецька ЛО, Тормахов ММ, Григоренко ОЯ. Ортодонтичні зусилля при лікуванні ретенованих зубів, обтяжених нестачею місця в зубному ряду. Новини стоматології. 2019;4(101):23-27.

15. Фліс ПС. Ортодонтія: підручник для студентів вищих навчальних закладів. Вінниця: Нова книга; 2007.312 с. 
16. Alqerban A, Jacobs R, Fieuws S, Willemsd G. Saudi Arabia Radiographic predictors for maxillary canine impaction. Am J Orthod Dentofacial Orthop. 2015 Mar;147(3):345-54.

17. Al-Zoubi H, Alharbi AA, Ferguson DJ, Zafar MS. Frequency of impacted teeth and categorization of impacted canines: A retrospective radiographic study using orthopantomograms. Eur J Dent. 2017 Jan-Mar; 11(1):117-121.

18. Dalessandri D, Parrini S, Rubiano R, Gallone D, Migliorati M. Impacted and transmigrant mandibular canines incidence, aetiology, and treatment: a systematic review. European Journal of Orthodontics. 2017; Apr 1;39(2):161-169.

19. Dersot JM. Periodontal surgery of the maxillary impacted canine for orthodontic purposes: Proposal for a surgical decision tree. International Orthodontics 2017 Jun;15(2): 221-237.

20. Jones DH, Kong YY, Penninger JM. Role of RANKL and RANK in bone loss and arthritis. Ann Rheum Dis. 2002 Nov;61(2):32-39.

21. Felicita A.S. Orthodontic management of a dilacerated central incisor and partially impacted canine with unilateral extraction - A case report. The Saudi Dental Journal. Saudi Dent J. 2017 Oct; 29(4): 185-193.

22. Ferreira JTL, Romano FL, Stuani MB, Assed Carneiro FC, Matsumoto MA. Traction of impacted canines in a skeletal Class III malocclusion: A challenging orthodontic treatment. Am J Orthod Dentofacial Orthop. 2017 Jun;151(6):11591168 .

\section{References}

1. Ahvazan A.A, Nedbah V.A, Kukuchkin V.A. Diagnostika i letchenie retencii rezcov. Orto-info. 2001;(2):35-37. (in Russian).

2. Golovko N.V., Golovko S.V., Korol D.M, ta in. Algoritm rozchifryvannia ortopantomogram. Ykrainskih stomatoloditchnih almanah. 2006;2(1): 9-11. (in Ukrainian).

3. Dmitrenko M.I. Zastosuvanna algoritmy likyvannia zybo-tchelepnih anomalih, yskladnenih skytchenistu zybiv. Likarska sprava. 2014;(1)2:72-77. (in Ukrainian).

4. Dobrih-vetchir T.V. Osoblivosti hiryrgitchnogo likyvannia hvorih z ytrydnenim prorizyvanniam nijnih tretih molariv [avtoreferat] Kiiv: Naz. med. yn-t. im.O.O. Bogomolza; 2011. 21c. (in Ukrainian).

5. Klityns'ka OV. Epidemiologitchnih analiz osoblivosteh bydovi ta fynkzionyvanna tchelehno-lizevogo aparaty y diteh Zakarpatia, iaki postihno metchkaut v ymovah mikroelementoziv. Molodih vtchenih. 2014; 8(11):112-114. (in Ukrainian).

6. Kononenko U.G., Rojko, M.M., Kindrat G.V., ta in. Dovidnik stomatologa. Metodi obstejenia, diagnostika, klinika, likyvanna. Ivano-Frankivsk: NAIR; 2013. 384 c. (in Ukrainian).

7. Minzer O.P., Voronenko U.V., Vlasov V.V. Obroblenna klinitchnih i eksperimentalnih danih v medizini: navtch. posibnik. Kiiv: Vitcha chkola; 2003. 350c. (in Ukrainian).

8. Osnatch R.G., Tormahov N.N., Beda A.V. Matematitcheskoe obosnovanie primenenie ortodontitcheskogo metoda zametchenia defekta zybnogo riada. Sovremennaia orthodontia/ 2014;(2):36-38. (in Russian).

9. Pilipiv N.V. Osoblivosti topitchnogo roztachyvannia retenovanih zybiv i ih sistematizacia. Ykrainskih stomatoloditchnih almanah.. 2013;(4):64 - 68. (in Ukrainian).

10. Rebrova O.U. Statistatchnih analuz medizinskih dannih. Primenenie paketa prikladnih programm STATISTIKA. Moskva:Media Sfera; 2002. 312 c. (in Russian).

11. Flis P.S., Brodezka L.O., vinahidniki; Nazionalnih meditchnih yniversitet imeni O.O.Vogomolza, patentovlasnik. Ortodontitchnih apparat dla likyvanna retenovanogo zyba z deficitom misza v zybnomy rady. Patent Ykraini № 136794 . 2019 Serpna 27. (in Ukrainian).

12. Flis P.S., Brodezka L.O., Natrys L.V., Licakovska O.O., vinahidniki; Nazionalnih meditchnih yniversitet imeni O.O.Vogomolza, patentovlasnik. Sposib remodeluvannia kistkovoi tkanini zubov. Patent Ykraini №136945. 2019 Verecen 10. (in Ukrainian).

13. Flis P.S., Brodezka L.O., Tormaxov M.M., Grugorenko O.Ya. Ortodontitchni zucilla pri likuvanni retenovanih zubiv, obtajenih nestatchtu micza v zybnomu rady. Novini stomatologii. 2019;4(101):23-27. (in Ukrainian).

Ukrainian).

15. Alqerban A, Jacobs R, Fieuws S, Willemsd G. Saudi Arabia Radiographic predictors for maxillary canine impaction. Am J Orthod Dentofacial Orthop. 2015 Mar;147(3):345-54.

16. Al-Zoubi H, Alharbi AA, Ferguson DJ, Zafar MS. Frequency of impacted teeth and categorization of impacted canines: A retrospective radiographic study using orthopantomograms. Eur J Dent. 2017 Jan-Mar; 11(1):117-121.

17. Dalessandri D, Parrini S, Rubiano R, Gallone D, Migliorati M. Impacted and transmigrant mandibular canines incidence, aetiology, and treatment: a systematic review. European Journal of Orthodontics. 2017; Apr 1;39(2):161-169.

18. Dersot JM. Periodontal surgery of the maxillary impacted canine for orthodontic purposes: Proposal for a surgical decision tree. International Orthodontics 2017 Jun;15(2): 221-237.

19. Jones DH, Kong YY, Penninger JM. Role of RANKL and RANK in bone loss and arthritis. Ann Rheum Dis. 2002 Nov;61(2):32-39. 
20. Felicita A.S. Orthodontic management of a dilacerated central incisor and partially impacted canine with unilateral extraction - A case report. The Saudi Dental Journal. Saudi Dent J. 2017 Oct; 29(4): 185-193.

21. Ferreira JTL, Romano FL, Stuani MB, Assed Carneiro FC, Matsumoto MA. Traction of impacted canines in a skeletal Class III malocclusion: A challenging orthodontic treatment. Am J Orthod Dentofacial Orthop. 2017 Jun;151(6):11591168 .

Дата надходження рукопису до редакції: 26.06 .2020 р.

Мета: підвищення ефективності ортодонтичного лікування ретенованих зубів (Р3) із нестачею місця в зубному ряду, шляхом мультидисциплінарного обгрунтування діагностично-лікувальних заходів на підставі вивчення молекулярних механізмів порушення кісткового ремоделювання процесів прорізування зубів та диференційованого застосування ортодонтичних зусиль залежно від виду прикусу.

Об’скт і методи дослідження. Обстежені (клінічними та рентгенологічними методами) та проліковані 109 пацієнтів віком 9-35 років із ретенованими зубами та нестачею місця в зубному ряду (62 в змінному прикусі, $47-$ в постійному). 18 пацієнтам проведено оцінку стану цитокінової системи в кістковій тканині альвеолярного відростку. Статистична обробка за допомогою комп’ютерних програм MS Exel тa Origin.

Результати. Ретенованими найчастіше були ікла 3 глибиною залягання до 7 мм із зміщенням в сагітальному напрямку та кутом нахилу більше $10^{\circ}$. Вивчення стану цитокінової системи RANKL/RANK/OPG та транскрипційного фактора NF-KB у пацієнтів з ретенцією зубів показало підвищення у 1,75 рази RANK, що свідчить про накопичення у зоні ретенції попередників остеокластів. Це дозволить ефективно застосовувати механічні зусилля для переміщення ретенованих зубів. Розроблений діагностично-лікувальний комплекс заходів для пацієнтів із ретенованими зубами складається мотиваційного, діагностичного та лікувального блоків.

Висновки. Розроблений мультидисциплінарний діагностично-лікувальний комплекс корекції ретенованих зубів з нестачею місця в зубному ряду достовірно скорочує терміни та підвищує ефективність лікування.

Ключові слова: ретеновані зуби, постійний прикус, змінний прикус, мультидисциплінарний підхід, ортодонтичне лікування.

Цель: повышение эффективности ортодонтического лечения ретенованых зубов при нехватке места в зубном ряду, путем мультидисциплинарного обоснования диагностически-лечебных мероприятий на основании изучения молекулярных механизмов нарушения костного ремоделирования процессов прорезывания зубов и дифференцированого применения ортодонтичних сил в зависимости от вида прикуса.

Объект и методы исследования. Обследованы (клиническими и рентгенологическими методами) и пролечены 109 пациентов в возрасте 9-35 лет с ретенированными зубами (62 в сменном прикусе, 47 - в постоянном). 18 пациентам проведено оценку состояния цитокиновой системы в костной ткане альвеолярного отростка. Статистическая оброботка результатов с помощью компьютерных программ MS Exel та Origin.

Результаты. Ретенированными чаще всего были клыки (глубиной залегания до 7 мм, смещением в саггитальном направлении под углом больше $10^{\circ}$. Изучение состояния цитокиновой системы RANKL/RANK/OPG и транскрипционного фактора NF-KB у пациентов с ретенцией зубов показало увеличение в 1,75 раза RANK, что свидетельствует о накоплении в зоне ретенции предшественников остеокластов. Это позволит эффективно применять механические усилия для перемещения зубов. Разработан диагностически-лечебный комплекс мероприятий, который состоит из следующих блоков: мотивационного, диагностического и лечебного.

Выводы. Применение мультидисциплинарного диагностически-лечебного комплекса мероприятий для пациентов с ретенированными зубами при недостаче места в зубном ряду достоверно сокращает сроки и повышает эффективность лечения таких пациентов.

Ключевые слова: ретенированные зубы, постоянный прикус, сменный прикус, мультидисциплинарный подход, ортодонтическое лечение.

Purpose: to increase the efficiency of orthodontic treatment of retained teeth with a lack of space in the dentition, through a multidisciplinary substantiation of diagnostic and therapeutic measures based on the study of the molecular mechanisms of bone remodeling disorders in the processes of teething and the differentiated use of orthodontic forces depending on the type of bite.

Object and research methods. Examined (by clinical and radiological methods) and treated 109 patients aged 9-35 years with retained teeth with a lack of space in the dentition (62 in a removable bite, 47 in a permanent). 20 patients were assessed for the state of the cytokine system in the bone tissue of the alveolar bone. Statistical processing of the results was carried out using computer programs MS Exel and Origin.

Results. According to x-ray studies, the fangs most often were fangs with a depth of up to $7 \mathrm{~mm}$ and displacement in the sagittal direction and an inclination angle of more than $10^{\circ}$. Investigation of the mechanisms of tooth eruption disorders - the study of the state of the RANKL/RANK/OPG cytokine system and the NF-KB transcription factor in patients with tooth retention 
showed a 1.75-fold increase in RANK, which indicates the accumulation of osteoclastic precursors in the retention zone. This will allow the effective use of mechanical forces to move the teeth. A diagnostic and treatment package has been developed for patients with retarded teeth with a lack of space in the dentition, depending on the period of occlusion, which consists of the following blocks: motivational, diagnostic and therapeutic.

Conclusions. A multidisciplinary diagnostic and treatment package has been developed and implemented for patients with retained teeth with insufficient space in the dentition, based on the determination of clinical and radiological characteristics, molecular mechanisms of bone remodeling disorders, strength and method of applying orthodontic efforts; its use significantly reduces the time and increases the effectiveness of orthodontic treatment of patients with retarded teeth, and in a removable bite, the treatment time is 1.7 times faster than in a permanent one.

Key words: retained teeth, permanent bite, removable bite, multidisciplinary approach, orthodontic treatment.

\section{Відомості про автора}

Бродецька Людмила Олександрівна - аспірант кафедри ортодонтії та пропедевтики ортопедичної стоматології Національного медичного університету імені О.О. Богомольця МОЗ України; 03179 м. Київ, вул. Зоологічна, 1. +380 (44) 483-13-02, klitinskaoksana@i.ua, ORCID ID 0000-0002-0570-3085. 